\title{
RESISTIN AND VISFATIN: REGULATORS OF INSULIN SENSITIVITY, INFLAMMATION AND IMMUNITY
}

\author{
STOFKova A \\ Department of Normal, Pathological and Clinical Physiology, Third Faculty of Medicine, Charles University in Prague, \\ Czech Republic \\ e-mail: andrea.stofkova@lf3.cuni.cz
}

\begin{abstract}
Adipokines play a significant role in the pathogenesis of a low-grade inflammation associated with obesity and metabolic syndrome, and in chronic inflammatory and autoimmune diseases such as rheumatoid arthritis. Among variety of adipokines, resistin and visfatin are proposed as important pro-inflammatory mediators, which also interfere with the central regulation of insulin sensitivity. Resistin has been initially postulated as a risk factor for insulin resistance, however, the subsequent available data on it have revealed contradictory findings in both humans and rodents. On the other hand, visfatin has been suggested to be a beneficial adipokine with insulin-mimicking/-sensitizing effects, but regulation of visfatin production and its physiological importance in the conditions of obesity and type 2 diabetes mellitus are still not completely understood. Despite the opposing effects of resistin and visfatin on the regulation of insulin sensitivity, both adipokines have pro-inflammatory properties. Clinical and experimental studies have shown that the expression and secretion of resistin and visfatin are up-regulated during inflammation and in response to pro-inflammatory cytokines. It has also become increasingly evident that resistin as well as visfatin itself can contribute to the inflammatory processes by triggering cytokine production and NF-kappaB activation. New insight into the role of adipokines makes them attractive targets for novel therapeutic strategies in chronic inflammatory diseases or subclinical inflammation relating to obesity and various metabolic abnormalities.
\end{abstract}

Key words: resistin, visfatin, obesity, insulin resistance, inflammation, autoimmunity, atherosclerosis, arthritis

\section{Resistin: Production and biological actions}

Resistin, also called FIZZ3 (found in inflammatory zone) or ADSF (adipocyte-specific secretory factor), was identified as a $12.5 \mathrm{kDa}$ polypeptide expressed and secreted by white adipose tissue. The term "resistin" was originally proposed for its role as a mediator of insulin resistance (STEPPAN et al. 2001). Resistin belongs to the family of cysteine-rich proteins, termed RELMs (resistin-like molecules). In its structure, cysteine resi- dues comprise 11 of 94 (12\%) amino acids (BANERJEE et al. 2001).

Resistin may be involved in sensing the nutritional status as its mRNA level is decreasing during fasting and increasing after food consumption (KIM et al. 2001; Steppan et al. 2001; Nogueiras et al. 2003; VAlsAMAKIS et al. 2004). Interestingly, its dramatic induction was found during 3T3-L1 and primary preadipocyte differentiation into adipocytes, and also was found its inhibitory effect on it, suggesting that resistin acts

Corresponding Author: PharmDr. Andrea Stofkova, Department of Normal, Pathological, and Clinical Physiology, Third Faculty of Medicine, Charles University in Prague, Ke Karlovu 4, 12000 Prague, Czech Republic, e-mail: andrea.stofkova@lf3.cuni.cz; Phone: +420 224902718; Fax: +420 224916896.

Conflict of interest: the author does not claim any conflict of interest. 
as a regulator of adipogenesis (НоLCOMB et al. 2000; KIM et al. 2001). In addition, resistin gene expression was significantly up-regulated by glucose and mediators known to increase plasma glucose levels such as glucocorticoids (Haugen et al. 2001; Shojima et al. 2002). The role of insulin in the regulation of resistin production has also been investigated, but there are conflicting data from studies. Kim et al. (2001) have shown increased resistin mRNA expression in adipose tissue of streptozotocin-diabetic mice upon insulin administration. On the contrary, other studies demonstrated that insulin administration resulted in suppressed resistin gene expression (Haugen et al. 2001; SHOJIMA et al. 2002; Kawashima et al. 2003; Liv et al. 2008). Furthermore, antidiabetic drugs thiazolidinediones (TZDs), which lower blood glucose by activating the nuclear receptor, peroxisome proliferator-activated receptor $\gamma(\operatorname{PPAR} \gamma)$, have been shown to also modulate resistin expression. However, both down-regulation (STEPPAN et al. 2001; Haugen et al. 2001; Shojima et al. 2002) and up-regulation (WAY et al. 2001; FukUI et al. 2002) of resistin gene expression have been reported after treatment with TZDs. Therefore, the modulation of resistin levels is presumably irrelevant for the antidiabetic effects of TZDs.

The most widely discussed biological effect of resistin has been the regulation of glucose homeostasis and insulin sensitivity. Although some studies confirmed impaired glucose tolerance and insulin action in response to resistin as well as positive correlation of increased circulating resistin levels with hyperinsulinemia and hyperglycemia (STEPPAN et al. 2001; RAJALA et al. 2004), these observations are not without controversy. In various models of rodent obesity associated with impaired insulin sensitivity, there was shown reduced resistin mRNA expression in adipose tissue (WAY et al. 2001; Juan et al. 2001; Milan et al. 2002; Fukui et al. 2002, Maebuchi et al. 2003; HaluziK et al. 2006) or in isolated adipocytes (LE LAY et al. 2001). In human studies, resistin circulating levels or gene expression have varied from increased to unchanged in obesity or type 2 diabetes mellitus (Degawa-Yamauchi et al. 2003; SAVAGe et al. 2001; Baranova et al. 2006; NAGAev et al. 2001; Heilbronn et al. 2004; Chen et al. 2006; Anderlova et al. 2007).

According to currently available data, the potential mechanisms of the resistin pro-diabetic effects could involve: (1) inhibition of the intrinsic activity of cell surface glucose transporters (Moon et al. 2003); (2) suppression of GLUT4 translocation (PALANivel et al. 2006) or its gene expression (Fu et al. 2006); (3) induction of inhibitor of insulin signaling, suppressor of cytokine signaling 3 (STEPPAN et al. 2005; BROWN et al. 2007); (4) blockade of insulin signal transduction pathways (SHENG et al. 2008); (5) stimulation of hepatic glucose production probably through decreased activity of AMP-activated protein kinase and increased expression of gluconeogenic enzymes in liver (BANERJEE et al. 2004); and (6) activation of free fatty acids release from adipose tissue (Pravenec et al. 2006). Nevertheless, resistin receptor and its downstream signaling pathways have not yet been identified.

Current evidence documents that resistin is also involved in food intake control at the central level. It has been reported that resistin is also expressed in the hypothalamus (Morash et al. 2002) and is able to activate hypothalamic neurons (BRUNETTI et al. 2004). Further study showed that central administration of resistin resulted in increased number of cells expressing Fos in the arcuate nucleus and promoted short-term satiety in rats (Tovar et al. 2005). Interestingly, anorectic effect of central resistin has been associated with decreased mRNA expression of orexigenic neuropeptides, neuropeptide $\mathrm{Y}(\mathrm{NPY})$ and agouti-related peptide (AgRP), and increased mRNA expression of anorexigenic cocaine and amphetamine-regulated transcript (CART) in the arcuate nucleus, as well as inhibition of hypothalamic fatty acid metabolism (VAzQuez et al. 2008). These findings demonstrate that resistin could be one of the factors involved in the hypothalamic anorexigenic pathway, similarly like leptin and insulin.

\section{Resistin in inflammation and autoimmunity}

Recent studies showed that resistin can also play a role in inflammation and autoimmunity. While in rodents resistin is predominantly expressed in adipocytes, analyses of resistin gene expression across a wide array of human tissues revealed that peripheral blood mononuclear cells (PBMCs), macrophages and bone marrow cells are a major source of human resistin (KASER et al. 2003; Patel et al. 2003). Therefore, in humans, resistin may be rather involved in the inflammatory processes than in the modulation of adiposity and glucose homeostasis.

Several studies demonstrated that inflammatory stimuli mediate resistin production. In human PBMCs, pro-inflammatory cytokines such as IL-1, IL-6 and TNF$\alpha$, as well as LPS have strongly induced resistin mRNA expression (KASER et al. 2003). On the other hand, 


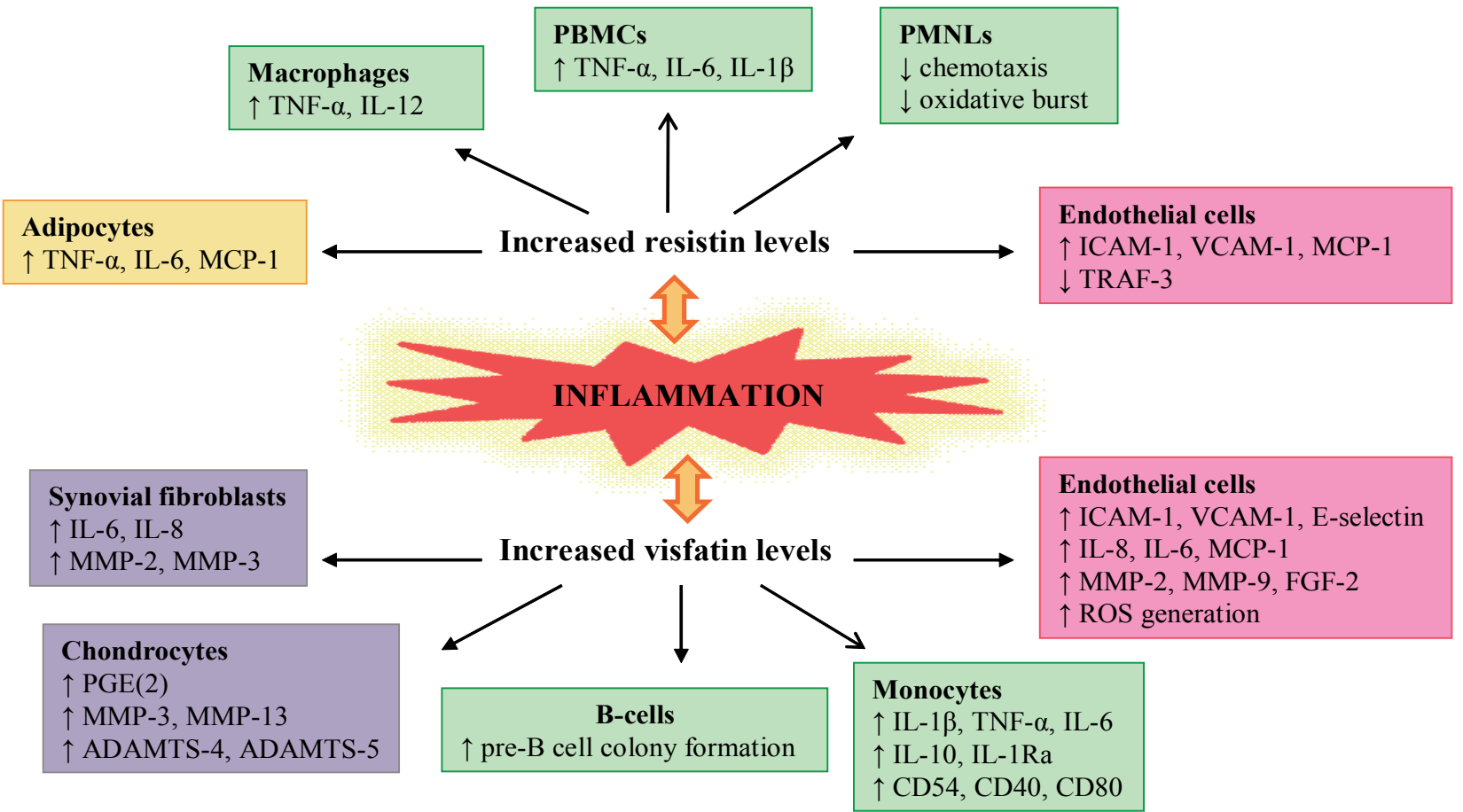

Figure 1: Involvement of resistin and visfatin in inflammation.

Inflammatory stimuli increase resistin and visfatin production. These adipokines act as specific immunomodulatory factors generating pro-inflammatory responses. Resistin stimulates adipocytes, macrophages and peripheral blood mononuclear cells (PBMCs) to produce pro-inflammatory cytokines, and innibits chemotaxis and oxidative burst of activated polymorphonuclear leukocytes (PMNLs). On endothelial cells, resistin induces expression of VCAM-1, ICAM-1 and monocyte chemoattractant protein-1 (MCP-1), and reduces expression of TNF receptor-associated factor-3 (TRAF-3). Visfatin, originally identified as preB-cell colony enhancing factor (PBEF), up-regulates the production of pro- and anti-inflammatory cytokines IL-1 $\beta$, TNF- $\alpha$, IL-6, IL-10 and IL-1 receptor antagonist (IL-1 Ra) in monocytes, and enhances the surface expression of the co-stimulatory molecules CD54, CD40 and CD80 in these cells. In joint inflammation, visfatin exhibits pro-inflammatory and matrix degrading effects by affecting the synthesis of metalloproteinases (MMPs), ADAMTS (a disintegrin and metalloproteinase with thrombospondin motifs), and PGE(2) in chondrocytes as well as pro-inflammatory cytokines and MMPs in synovial fibroblasts. Visfatin with its pro-inflammatory effects on endothelial cells may also influence the process of atherosclerosis inducing ICAM-1, VCAM-1, E-selectin, IL-8, IL-6, MCP-1, fibroblast growth factor-2 (FGF-2), and metalloproteinases MMP-2/-9 production as well as ROS (reactive oxygen species) generation.

in adipocytes and preadipocytes, TNF- $\alpha$ administration significantly decreased resistin mRNA expression (FASSHAUER et al. 2001; Li et al. 2003). Interestingly, LPS stimulated resistin mRNA levels in both types of cells, adipocytes and white blood cells in vivo and in vitro (Lu et al. 2002; LeHrke et al. 2004).

Resistin, per se, acts as a pro-inflammatory factor (Fig. 1). In human as well as macrophage culture resistin enhanced secretion of pro-inflammatory cytokines, TNF- $\alpha$ and IL-12, and was able to induce the nuclear translocation of NF-kappaB transcription factor (SILSWAL et al. 2005). In 3T3-L1 adipocytes resistin potentiated TNF- $\alpha$, IL- 6 and monocyte chemoattractant protein- 1
(MCP-1) production (Fu at al. 2006). Moreover, stimulation of human PBMC with recombinant resistin led to a marked up-regulation of the genes for TNF- $\alpha$, IL- 6 , IL- $1 \beta$, and resistin itself, showing that resistin induces a positive feedback mechanism on its own expression (BOKAREWA et al. 2005). Resistin also suppressed chemotaxis of human polymorphonuclear leukocytes (PMNLs) and decreased the oxidative burst stimulated by Escherichia coli and by phorbol myristate acetate, but did not affect PMNL phagocytosis (CoHEN et al. 2008). In addition, exposure of cultured human hepatic stellate cells to recombinant resistin caused increased expression of MCP- 1 and IL-8 through activation of $\mathrm{Ca}^{2+} / \mathrm{NF}-$ 
кB dependent pathway (BERTolani et al. 2006). Finally, resistin significantly enhanced hepatic inflammation and necrosis in LPS-induced liver damage in mice. This effect of resistin was presumably mediated via activation of mechanisms involving the coagulation cascade and fibrin accumulation (BEIER et al. 2008).

Recent studies indicate that the pathogenesis of atherosclerosis is highly connected with resistin-induced inflammatory process. Resistin has been demonstrated to directly induce expression of VCAM-1, ICAM-1 and MCP-1, and concomitantly reduce TNF receptor-associated factor-3 (TRAF-3) expression on endothelial cells (Verma et al. 2003; Kawanami et al. 2004). Calabro et al. (2004) reported that resistin also activates human aortic smooth muscle cells through both extracellular signal-related kinase 1/2 and Akt signaling pathways. Moreover, resistin promotes macrophage-foam cell formation by affecting class A scavenger receptor, CD 36 and ATP-binding cassette transporter-A1 in macrophages (LeE et al. 2009).

Resistin likely plays an important role in chronic inflammatory and autoimmune diseases. In inflammatory bowel disease, it has been shown that circulating resistin levels were elevated and correlated with white blood cell count, C-reactive protein (CRP) levels and disease activity (KonRAD et al. 2007). The increased circulating resistin levels were also observed in patients with chronic pancreatitis suggesting its impact on pancreatic fibrosis development (ADRYCH et al. 2008). In patients with SLE, similar serum resistin levels to those in controls were reported. However, circulating resistin level was clearly associated with general inflammation, renal disease, treatment with glucocorticoids, and bone loss in SLE patients (ALMEHED et al. 2008).

There are also data which clearly indicate a pro-inflammatory effect of resistin in pathogenesis of arthritis. Healthy mice injected with recombinant mouse resistin into knee joints developed arthritis and showed infiltration of synovial tissue with leucocytes associated with hypertrophy of synovial lining layer and panus formation (BOKAREwA et al. 2005). In human RA, there were revealed increased synovial fluid resistin levels, correlated with elevated resistin expression in synovial sublining layers, abundant accumulation of inflammatory cells or IL-6 synovial fluid levels (BOKAREwA et al. 2005; Senolt et al. 2007). However, existing studies differ in results on circulating resistin levels in RA patients. While some studies showed unaltered resistin serum levels in RA patients compared to controls (BOKAREWA et al. 2005; Otero et al. 2006; Forsblad d’Elia et al.
2008), Migita et al. (2006) found higher serum resistin levels, correlated with RA disease activity markers, CRP, TNF- $\alpha$, and erythrocyte sedimentation rate. In rat model of RA, adjuvant arthritis (AA), we observed unchanged circulating resistin levels compared to controls in the clinical phase of the disease (JuRcovicova et al. 2009).

At the joint cartilage level, LeE et al. (2009) have reported direct effect of resistin in stimulation of proteoglycan degradation in mouse cartilage cultures, and in proteoglycan biosynthesis inhibition in human cartilage explants. Furthermore, treatment of mouse cartilage cultures with recombinant resistin induced pro-inflammatory cytokines and PGE(2) production (LEE et al., 2009). With regard to these findings, increased systemic and local cartilage resistin levels during arthritis may enhance joint inflammation.

\section{Visfatin: Production and biological actions}

Visfatin, an adipokine isolated by FuKUHARA et al. (2005), corresponds to a protein identified previously as pre- $\mathrm{B}$ cell colony-enhancing factor (PBEF), a $52 \mathrm{kDa}$ cytokine expressed and secreted by lymphocytes ( $\mathrm{SA}_{\mathrm{A}}$ MAL et al. 1994). Visfatin is also called NAMPT because of its significant sequence and functional homology with nicotinamide phosphoribosyltransferase (NAmPRTase), an enzyme involved in nicotinamide adenine dinucleotide (NAD) biosynthesis from nicotinamide (Rongvaux et al. 2002). The term "visfatin" was adopted for this protein because of its predominant production in visceral adipose tissue (FukUHARA et al. 2005; PAGANo et al. 2006). However this observation was not always confirmed by further studies; e.g. BERNDT et al. (2005) reported no differences in visfatin mRNA expression between visceral and subcutaneous adipose tissue in humans.

The biological role of visfatin is not entirely understood, but several studies indicated glucose lowering and insulin-mimicking/-sensitizing effects of visfatin. Mice heterozygous for a target mutation in the visfatin gene had modestly higher levels of plasma glucose (FukuHara et al. 2005), impaired glucose tolerance and reduced glucose-stimulated insulin secretion relative to control mice (Revollo et al. 2007). Initial studies showed that visfatin exerted insulin-mimetic effects in various insulin-sensitive cell cultures through binding to insulin receptor at a site distinct from insulin and stimulated phosphorylation of insulin receptor, insulin receptor substrate- 1 and -2 (IRS- 1 and IRS-2), and 
downstream signaling kinases: protein kinase B (Akt) and mitogen-activated protein kinase (MAPK). In vitro, visfatin treatment enhanced glucose uptake in 3T3-L1 adipocytes and L6 myocytes, and suppressed glucose release in hepatocytes (FukUhara et al. 2005). Interestingly, the transfection of visfatin plasmid enhanced plasma visfatin level, improved insulin sensitivity or displayed hypocholesterolemic effects in normal-chow rats and rats on high-fat diet (QIN et al. 2008; Sun et al. 2009). These effects were mediated at least partially through up-regulation of the tyrosine phosphorylation of IRS- 1 protein, and the mRNA levels of PPAR- $\gamma$ and sterol regulatory element-binding proteins 2 (Sun et al. 2009). Insulin-like effects of visfatin have been also described on human osteoblasts where visfatin induced tyrosine phosphorylation of insulin receptor, IRS-1 and IRS-2 (XIE at al. 2007). However, another study described that visfatin does not have insulin-mimetic effects, but rather functions as an extracellular NAD biosynthetic enzyme (NAMPT) critical for glucose-stimulated insulin secretion in pancreatic $\beta$-cells (Revollo et al. 2007). Moreover, stimulation of GLUT1 protein expression and migration into cellular membranes has been also described as one of mechanisms of visfatin actions on mesangial cells (SoNG et al. 2008).

According to above mentioned beneficial effects of visfatin on glucose homeostasis, visfatin has been speculated to provide a compensatory mechanism in response to hyperglycemia in conditions of insulin resistance. The in vitro experiments demonstrated direct effect of glucose on visfatin release from adipocytes that depended on the PI3-kinase/Akt pathway activation (HAIDER at al. 2006b). However, it seems that visfatin production is regulated by glucose upon time-dependent stimulation since short-time period of glucose elevation, observed at 60 and 120 minute of the oral glucose tolerance test, did not altered circulating visfatin levels in humans (MARCINKowsKa et al. 2007). Up-regulation of visfatin levels in states of hyperglycaemia for a prolonged period, i.e. in patients with diabetes mellitus, has been observed in several studies (CHEN et al. 2006; Hammarstedt et al. 2006; Lopez-Bermejo et al. 2006). However, BERNDT et al. (2005) did not found significant correlation of plasma visfatin levels and parameters of insulin sensitivity, including fasting insulin, fasting plasma glucose concentrations, and the glucose infusion rate during the steady state of a euglycemichyperinsulinemic clamp independent of percent body fat. There are also conflicting data on visfatin circulating levels in obese humans. Some studies confirmed the increased levels of circulating visfatin (HAIDER et al. 2006a; ZAHORSKA-MARKIEWICZ et al. 2007; JiN et al. 2008; Davutoglu et al. 2009), but there is also a study which showed reduced plasma visfatin levels in obese subjects (Pagano et al. 2006). Paradoxically, both weight reduction (Haider et al. 2006c; MANCo et al. 2007; De Luis et al. 2008; SHeu et al. 2008) as well as overnutrition down-regulated circulating visfatin concentrations in humans (Sun et al. 2007). The controversial findings on visfatin levels, reaching the increased (FuKuHARA et al. 2005), unchanged (KLOTING and KLOTING 2005; Stofkova et al. 2009) or decreased levels (Mercader et al. 2008) during the obesity and metabolic syndrome were also reported in various rat or mouse models of obesity. According to these observations in humans and animals, the regulation of visfatin production under the conditions of obesity and diabetes mellitus is not completely clear and also seems to differ across the species and genetic background.

\section{Visfatin in inflammation and autoimmunity}

Visfatin is not only an adipocyte-specific protein. The expression of visfatin gene was originally found in human peripheral blood lymphocytes, and was termed pre$\mathrm{B}$ cell colony-enhancing factor (PBEF) as it increased the effect of IL-7 and stem-cell factor on pre-B-cell colony formation (SAmaL et al. 1994).

Visfatin appears to be an important mediator of inflammation (Fig. 1). Moschen et al. (2007) demonstrated that recombinant visfatin induced dose-dependent production of pro-inflammatory IL- $1 \beta$, TNF- $\alpha$, and IL-6 as well as anti-inflammatory cytokines like IL-10, and IL-1 receptor antagonist in human monocytes. Moreover, visfatin enhanced the surface expression of the co-stimulatory molecules important to activate T cells, such as CD54 (ICAM-1), CD40 and CD80 in monocytes, and was able to act as a potent chemotactic factor for $\mathrm{CD} 14^{+}$monocytes and $\mathrm{CD} 19^{+} \mathrm{B}$ cells. In vivo, i.p. injection of recombinant murine visfatin significantly increased circulating IL-6 levels and IL-6 mRNA expression in the small intestine in mice (Moschen et al. 2007). Other study demonstrated that visfatin was also synthesized and released by neutrophils in response to inflammatory stimuli and that it functioned as an inhibitor of apoptosis resulting from variety of inflammatory stimuli. For example, visfatin was expressed at high levels in neutrophils harvest from septic critically ill patients and contributed to prolonged neutrophil survival in clinical sepsis (JIA et al. 2004). 
Interestingly, pharmacological inhibition of visfatin reduced the intracellular concentration of NAD in inflammatory cells and circulating TNF- $\alpha$ level during endotoxemia in mice. Thus, visfatin links NAD metabolism to inflammatory cytokine secretion by leukocytes (Busso et al. 2008). In addition, lack of visfatin expression strongly affected the development of both $\mathrm{T}$ and B lymphocytes and deteriorated cellular resistance to genotoxic/oxidative stress. These findings indicate that visfatin may confer to cells of the immune system the ability to survive during stressful situations such as inflammation (Rongvaux et al. 2008).

Visfatin with its pro-inflammatory effects could promote the process of atherosclerosis. In vitro, visfatin increased leukocyte adhesion to endothelial cells by induction of the cell adhesion molecules ICAM-1, VCAM-1 and E-selectin, and expression of IL-6 and IL-8 in the conditioned medium of endothelial cells (Кiм et al. 2008; LEE et al. 2009). Additionally, visfatin treatment led to ROS (reactive oxygen species) generation (KIM et al. 2008), and activation of a potent angiogenic factors including endothelial fibroblast growth factor-2 (FGF-2) (BAE et al. 2009), and matrix metalloproteinase (MMP) -2 and -9 (ADyA et al. 2008) as well as MCP-1 and its putative receptor CCR2 in endothelial cells (ADYA et al. 2009). Further data also suggest a potential role of visfatin in plaque destabilization. Visfatin gene expression was markedly enhanced in carotic plaques from symptomatic individuals (DAHL et al. 2007). Importantly, both oxidized low-density lipoprotein and TNF- $\alpha$ increased visfatin expression in THP-1 monocytes (DAHL et al. 2007). On the other hand, visfatin gene expression in adipocytes has been found to be negatively regulated by TNF- $\alpha$ and IL-6 (Kralisch et al. 2005a; KrALISCH et al. 2005b; Li et al. 2009).

Notably, several inflammatory conditions including acute lung injury (YE et al. 2005), chronic obstructive pulmonary disease (Liv et al. 2009), inflammatory bowel disease (Moschen et al. 2007), psoriasis (KoczAn et al. 2005) and rheumatoid arthritis (OTERo et al. 2006; MAtsui et al. 2008) are accompanied by visfatin upregulation. Significantly higher visfatin gene expression was found in synovial tissue, PBMC and peripheral blood granulocytes (PBG) in patients with RA compared to healthy controls (MATsui et al. 2008). NowELL et al. (2006) described regulation of visfatin production via STAT-3-dependent IL-6 trans-signaling in synovial fibroblasts in RA. BRENTANO et al. (2007) reported that the TLR-2 ligand bacterial lipoprotein, the TLR-4 ligand LPS, IL- $1 \beta$, TNF- $\alpha$, and visfatin itself up-regulated visfatin mRNA in RA synovial fibroblasts. Moreover, visfatin itself activated NF-kappaB and activator protein 1, and induced IL-6, IL-8, MMP-1 and MMP-3 in RA synovial fibroblasts (BRENTANo et al. 2007). Additionally, visfatin serum and synovial fluid levels positively correlated with the degree of inflammation and clinical disease activity in RA patients (BRENTANo et al. 2007).

Visfatin may also have a possible inflammatory influence on osteoarthritis (OA). Although visfatin circulating levels were found lower in OA patients than in RA patients (MATsui et al. 2008), visfatin was highly produced in human OA chondrocytes (Gosset et al. 2008). In searching for the functions of visfatin in OA-affected human chondrocytes, Gosset et al. (2008) found that visfatin, similarly like IL- $1 \beta$, triggers excessive release of PGE(2), due to increase of microsomal PGE synthase 1 and decrease of $\mathrm{NAD}^{+}$-dependent 15-hydroxy-PG dehydrogenase synthesis. In this study, visfatin also stimulated MMP-3 and MMP-13 synthesis and expression of a disintegrin and metalloproteinase (ADAMTS) -4 and -5 that indicated catabolic function of visfatin in chondrocytes (Gosset et al. 2008). The increased visfatin circulating levels were also confirmed in adjuvant arthritic rats (Jurcovicova et al. 2009) and mice with collageninduced arthritis compared to healthy controls (Busso et al. 2008). Moreover, the severity of arthritis in mice was reduced by a specific inhibitor of NAMPT/visfatin enzymatic function (Busso et al. 2008). Overall, these observations provide the evidence that visfatin could be considered as a pro-inflammatory and destructive mediator in arthritis. Thus, visfatin quantification may serve as a marker of the degree of inflammation and disease activity.

\section{Acknowledgements}

This work was supported by grant No. VZ 00216 20816. 


\section{References}

Adya R, Tan BK, Chen J, Randeva HS: Nuclear factor-kappaB induction by visfatin in human vascular endothelial cells: its role in MMP-2/9 production and activation. Diabetes Care 31, 758-760, 2008 doi:10.2337/dc07-1544

Adya R, Tan BK, Chen J, Randeva HS: Pre-B cell colony enhancing factor (PBEF)/visfatin induces secretion of MCP-1 in human endothelial cells: role in visfatin-induced angiogenesis. Atherosclerosis 205, 113-119, 2009 doi:10.1016/ j.atherosclerosis.2008.11.024

Adrych K, Smoczynski M, Sledzinski T, Dettlaff-Pokora A, Goyke E, Swierczynski J: Increased Serum Resistin Concentration in Patients With Chronic Pancreatitis: Possible Cause of Pancreatic Fibrosis. J Clin Gastroenterol 2008 Sep 29. [Epub ahead of print]

Almehed K, d'Elia HF, Bokarewa M, Carlsten H: Role of resistin as a marker of inflammation in systemic lupus erythematosus. Arthritis Res Ther 10, R15, 2008 doi:10.1186/ar2366

Anderlova K, Dolezalova R, Housova J, Bosanska L, Haluzikova D, Kremen J, Skrha J, Haluzik M: Influence of PPARalpha agonist fenofibrate on insulin sensitivity and selected adipose tissue-derived hormones in obese women with type 2 diabetes. Physiol Res 56, 579-586, 2007

Banerjee RR, Lazar MA: Dimerization of resistin and resistin-like molecules is determined by a single cysteine. J Biol Chem 276, 25970-25973, 2001 doi:10.1074/jbc.M103109200

Banerjee RR, Rangwala SM, Shapiro JS, Rich AS, Rhoades B, Qi Y, Wang J, Rajala MW, Pocai A, Scherer PE, Steppan CM, Ahima RS, Obici S, Rossetti L, Lazar MA: Regulation of fasted blood glucose by resistin. Science 303, 1195-1198, 2004 doi:10.1126/science.1092341

Baranova A, Gowder SJ, Schlauch K, Elariny H, Collantes R, Afendy A, Ong JP, Goodman Z, Chandhoke V, Younossi ZM: Gene expression of leptin, resistin, and adiponectin in the white adipose tissue of obese patients with non-alcoholic fatty liver disease and insulin resistance. Obes Surg 16, 1118-1125, $2006 \underline{\text { doi:10.1381/096089206778392149 }}$

Beier JI, Guo L, von Montfort C, Kaiser JP, Joshi-Barve S, Arteel GE: New role of resistin in lipopolysaccharide-induced liver damage in mice. J Pharmacol Exp Ther 325, 801-808, 2008 doi:10.1124/jpet.108.136721

Berndt J, Kloting N, Kralisch S, Kovacs P, Fasshauer M, Schon MR, Stumvoll M, Bluher M: Plasma visfatin concentrations and fat depot-specific mRNA expression in humans. Diabetes 54, 2911-2916, 2005 doi:10.2337/ diabetes.54.10.2911

Bertolani C, Sancho-Bru P, Failli P, Bataller R, Aleffi S, DeFranco R, Mazzinghi B, Romagnani P, Milani S, Gines P, Colmenero J, Parola M, Gelmini S, Tarquini R, Laffi G, Pinzani M, Marra F: Resistin as an intrahepatic cytokine: overexpression during chronic injury and induction of proinflammatory actions in hepatic stellate cells. Am J Pathol 169, 2042-2053, 2006 doi:10.2353/ajpath.2006.060081

Bokarewa M, Nagaev I, Dahlberg L, Smith U, Tarkowski A: Resistin, an adipokine with potent proinflammatory properties. J Immunol 174, 5789-5795, 2005

Brentano F, Schorr O, Ospelt C, Stanczyk J, Gay RE, Gay S, Kyburz D: Pre-B cell colony-enhancing factor/visfatin, a new marker of inflammation in rheumatoid arthritis with proinflammatory and matrix-degrading activities. Arthritis Rheum 56, 2829-2839, 2007 doi:10.1002/art.22833

Brown R, Imran SA, Belsham DD, Ur E, Wilkinson M: Adipokine gene expression in a novel hypothalamic neuronal cell line: resistin-dependent regulation of fasting-induced adipose factor and SOCS-3. Neuroendocrinology 85 , 232-241, 2007 doi:10.1159/000104248

Brunetti L, Orlando G, Recinella L, Michelotto B, Ferrante C, Vacca M: Resistin, but not adiponectin, inhibits dopamine and norepinephrine release in the hypothalamus. Eur J Pharmacol 493, 41-44, 2004 doi:10.1016/ j.ejphar.2004.04.020

Busso N, Karababa M, Nobile M, Rolaz A, Van Gool F, Galli M, Leo O, So A, De Smedt T: Pharmacological inhibition of nicotinamide phosphoribosyltransferase/visfatin enzymatic activity identifies a new inflammatory pathway linked to NAD. PLoS ONE 3, e2267, 2008 doi:10.1371/journal.pone.0002267

Calabro P, Samudio I, Willerson JT, Yeh ET: Resistin promotes smooth muscle cell proliferation through activation of extracellular signal-regulated kinase 1/2 and phosphatidylinositol 3-kinase pathways. Circulation 110, 3335-3340, 2004 doi:10.1161/01.CIR.0000147825.97879.E7

Chen MP, Chung FM, Chang DM, Tsai JC, Huang HF, Shin SJ, Lee YJ: Elevated plasma level of visfatin/pre-B cell colony-enhancing factor in patients with type 2 diabetes mellitus. J Clin Endocrinol Metab 91, 295-299, 2006 doi:10.1210/jc.2005-1475

Cohen G, Ilic D, Raupachova J, Horl WH: Resistin inhibits essential functions of polymorphonuclear leukocytes. J Immunol 181, 3761-3768, 2008 
Dahl TB, Yndestad A, Skjelland M, Oie E, Dahl A, Michelsen A, Damas JK, Tunheim SH, Ueland T, Smith C, Bendz B, Tonstad S, Gullestad L, Froland SS, Krohg-Sørensen K, Russell D, Aukrust P, Halvorsen B: Increased expression of visfatin in macrophages of human unstable carotid and coronary atherosclerosis: possible role in inflammation and plaque destabilization. Circulation 115, 972-980, 2007 doi:10.1161/CIRCULATIONAHA.106.665893

Davutoglu M, Ozkaya M, Guler E, Garipardic M, Gursoy H, Karabiber H, Kilinc M: Plasma visfatin concentrations in childhood obesity: relationships with insulin resistance and anthropometric indices. Swiss Med Wkly 139, 22-27, 2009

De Luis DA, Gonzalez Sagrado M, Conde R, Aller R, Izaola O, Romero E: Effect of a hypocaloric diet on serum visfatin in obese non-diabetic patients. Nutrition 24, 517-521, 2008 doi:10.1016/j.nut.2008.01.052

Degawa-Yamauchi M, Bovenkerk JE, Juliar BE, Watson W, Kerr K, Jones R, Zhu Q, Considine RV: Serum resistin (FIZZ3) protein is increased in obese humans. J Clin Endocrinol Metab 88, 5452-5455, 2003 doi:10.1210/jc.2002-021808

Fasshauer M, Klein J, Neumann S, Eszlinger M, Paschke R: Tumor necrosis factor alpha is a negative regulator of resistin gene expression and secretion in 3T3-L1 adipocytes. Biochem Biophys Res Commun 288, 1027-1031, 2001 doi:10.1006/bbrc.2001.5874

Fu Y, Luo L, Luo N, Garvey WT: Proinflammatory cytokine production and insulin sensitivity regulated by overexpression of resistin in 3T3-L1 adipocytes. Nutr Metab (Lond) 19, 28, $2006 \underline{\text { doi:10.1186/1743-7075-3-28 }}$

Fukuhara A, Matsuda M, Nishizawa M, Segawa K, Tanaka M, Kishimoto K, Matsuki Y, Murakami M, Ichisaka T, Murakami H, Watanabe E, Takagi T, Akiyoshi M, Ohtsubo T, Kihara S, Yamashita S, Makishima M, Funahashi T, Yamanaka S, Hiramatsu R, Matsuzawa Y, Shimomura I: Visfatin: a protein secreted by visceral fat that mimics the effects of insulin. Science 307, 426-430, 2005 doi:10.1126/science.1097243

Fukui Y, Motojima K: Expression of resistin in the adipose tissue is modulated by various factors including peroxisome proliferator-activated receptor alpha. Diabetes Obes Metab 4, 342-345, 2002 doi:10.1046/j.1463-1326.2002.00215.x

Forsblad d'Elia H, Pullerits R, Carlsten H, Bokarewa M: Resistin in serum is associated with higher levels of IL-1Ra in post-menopausal women with rheumatoid arthritis. Rheumatology (Oxford) 47, 1082-1087, 2008 doi:10.1093/ rheumatology/ken187

Gosset M, Berenbaum F, Salvat C, Sautet A, Pigenet A, Tahiri K, Jacques C: Crucial role of visfatin/pre-B cell colonyenhancing factor in matrix degradation and prostaglandin E2 synthesis in chondrocytes: possible influence on osteoarthritis. Arthritis Rheum 58, 1399-1409, 2008 doi:10.1002/art.23431

Haider DG, Holzer G, Schaller G, Weghuber D, Widhalm K, Wagner O, Kapiotis S, Wolzt M: The adipokine visfatin is markedly elevated in obese children. J Pediatr Gastroenterol Nutr 43, 548-549, 2006a doi:10.1097/01. mpg.0000235749.50820.b3

Haider DG, Schaller G, Kapiotis S, Maier C, Luger A, Wolzt M: The release of the adipocytokine visfatin is regulated by glucose and insulin. Diabetologia 49, 1909-1914, 2006b doi:10.1007/s00125-006-0303-7

Haider DG, Schindler K, Schaller G, Prager G, Wolzt M, Ludvik B: Increased plasma visfatin concentrations in morbidly obese subjects are reduced after gastric banding. J Clin Endocrinol Metab 91, 1578-1581, 2006c doi:10.1210/jc.2005-2248

Haluzik MM, Lacinova Z, Dolinkova M, Haluzikova D, Housa D, Horinek A, Vernerova Z, Kumstyrova T, Haluzik M: Improvement of insulin sensitivity after peroxisome proliferator-activated receptor-alpha agonist treatment is accompanied by paradoxical increase of circulating resistin levels. Endocrinology 147, 4517-4524, 2006 doi:10.1210/en.2005-1624

Hammarstedt A, Pihlajamaki J, Rotter Sopasakis V, Gogg S, Jansson PA, Laakso M, Smith U: Visfatin is an adipokine, but it is not regulated by thiazolidinediones. J Clin Endocrinol Metab 91, 1181-1184, 2006 doi:10.1210/jc.2005-1395

Haugen F, Jorgensen A, Drevon CA, Trayhurn P: Inhibition by insulin of resistin gene expression in 3T3-L1 adipocytes. FEBS Lett 507, 105-108, 2001 doi:10.1016/S0014-5793(01)02968-4

Heilbronn LK, Rood J, Janderova L, Albu JB, Kelley DE, Ravussin E, Smith SR: Relationship between serum resistin concentrations and insulin resistance in nonobese, obese, and obese diabetic subjects. J Clin Endocrinol Metab 89, 1844-1888, 2004 doi:10.1210/jc.2003-031410

Holcomb IN, Kabakoff RC, Chan B, Baker TW, Gurney A, Henzel W, Nelson C, Lowman HB, Wright BD, Skelton NJ, Frantz GD, Tumas DB, Peale FV Jr, Shelton DL, Hebert CC: FIZZ1, a novel cysteine-rich secreted protein associated with pulmonary inflammation, defines a new gene family. EMBO J 19, 4046-4055, 2000 doi:10.1093/ emboj/19.15.4046 Juan CC, Au LC, Fang VS, Kang SF, Ko YH, Kuo SF, Hsu YP, Kwok CF, Ho LT: Suppressed gene expression of adipocyte resistin in an insulin-resistant rat model probably by elevated free fatty acids. Biochem Biophys Res Commun 289, 1328-1333, 2001 doi:10.1006/bbrc.2001.6132

Jurcovicova J, Stofkova A, Skurlova M, Baculikova M, Zorad S, Stancikova M: Alterations in adipocyte glucose transporter GLUT4 and circulating adiponectin and visfatin in rat adjuvant induced arthritis. Gen Physiol Biophys 2009 accepted 
Jia SH, Li Y, Parodo J, Kapus A, Fan L, Rotstein OD, Marshall JC: Pre-B cell colony-enhancing factor inhibits neutrophil apoptosis in experimental inflammation and clinical sepsis. J Clin Invest 113, 1318-1327, 2004 Jin H, Jiang B, Tang J, Lu W, Wang W, Zhou L, Shang W, Li F, Ma Q, Yang Y, Chen M: Serum visfatin concentrations in obese adolescents and its correlation with age and high-density lipoprotein cholesterol. Diabetes Res Clin Pract 79, 412-419, 2008 doi:10.1016/j.diabres.2007.09.019

Kaser S, Kaser A, Sandhofer A, Ebenbichler CF, Tilg H, Patsch JR: Resistin messenger-RNA expression is increased by proinflammatory cytokines in vitro. Biochem Biophys Res Commun 309, 286-290, 2003 doi:10.1016/ j.bbrc.2003.07.003

Kawanami D, Maemura K, Takeda N, Harada T, Nojiri T, Imai Y, Manabe I, Utsunomiya K, Nagai R: Direct reciprocal effects of resistin and adiponectin on vascular endothelial cells: a new insight into adipocytokine-endothelial cell interactions. Biochem Biophys Res Commun 314, 415-419, 2004 doi:10.1016/j.bbrc.2003.12.104

Kawashima J, Tsuruzoe K, Motoshima H, Shirakami A, Sakai K, Hirashima Y, Toyonaga T, Araki E: Insulin down-regulates resistin mRNA through the synthesis of protein(s) that could accelerate the degradation of resistin mRNA in 3T3-L1 adipocytes. Diabetologia 46, 231-240, 2003

Kim KH, Lee K, Moon YS, Sul HS: A cysteine-rich adipose tissue-specific secretory factor inhibits adipocyte differentiation. J Biol Chem 276, 11252-11256, 2001 doi:10.1074/jbc.C100028200

Kim SR, Bae YH, Bae SK, Choi KS, Yoon KH, Koo TH, Jang HO, Yun I, Kim KW, Kwon YG, Yoo MA, Bae MK: Visfatin enhances ICAM-1 and VCAM-1 expression through ROS-dependent NF-kappaB activation in endothelial cells. Biochim Biophys Acta 1783, 886-895, 2008 doi:10.1016/j.bbamcr.2008.01.004

Kloting N, Kloting I: Visfatin: gene expression in isolated adipocytes and sequence analysis in obese WOKW rats compared with lean control rats. Biochem Biophys Res Commun 332, 1070-1072, 2005 doi:10.1016/j.bbrc.2005.05.058

Koczan D, Guthke R, Thiesen HJ, Ibrahim SM, Kundt G, Krentz H, Gross G, Kunz M: Gene expression profiling of peripheral blood mononuclear leukocytes from psoriasis patients identifies new immune regulatory molecules. Eur J Dermatol 15, 251-257, 2005

Konrad A, Lehrke M, Schachinger V, Seibold F, Stark R, Ochsenkuhn T, Parhofer KG, Goke B, Broedl UC: Resistin is an inflammatory marker of inflammatory bowel disease in humans. Eur J Gastroenterol Hepatol 19, 1070-1074, 2007 doi:10.1097/MEG.0b013e3282f16251

Kralisch S, Klein J, Lossner U, Bluher M, Paschke R, Stumvoll M, Fasshauer M: Hormonal regulation of the novel adipocytokine visfatin in 3T3-L1 adipocytes. J Endocrinol 185, R1-R8, 2005a Kralisch S, Klein J, Lossner U, Bluher M, Paschke R, Stumvoll M, Fasshauer M: Interleukin-6 is a negative regulator of visfatin gene expression in 3T3-L1 adipocytes. Am J Physiol Endocrinol Metab 289, E586-E590, 2005b

Le Lay S, Boucher J, Rey A, Castan-Laurell I, Krief S, Ferre P, Valet P, Dugail I: Decreased resistin expression in mice with different sensitivities to a high-fat diet. Biochem Biophys Res Commun 289, 564-567, 2001 doi:10.1006/bbrc.2001.6015

Lee JH, Bullen JW Jr, Stoyneva VL, Mantzoros CS: Circulating resistin in lean, obese, and insulin-resistant mouse models: lack of association with insulinemia and glycemia. Am J Physiol Endocrinol Metab 288, E625-E632, 2005 doi:10.1152/ajpendo.00184.2004

Lee JH, Ort T, Ma K, Picha K, Carton J, Marsters PA, Lohmander LS, Baribaud F, Song XY, Blake S: Resistin is elevated following traumatic joint injury and causes matrix degradation and release of inflammatory cytokines from articular cartilage in vitro. Osteoarthritis Cartilage 17, 613-620, 2009 doi:10.1016/j.joca.2008.08.007

Lee TS, Lin CY, Tsai JY, Wu YL, Su KH, Lu KY, Hsiao SH, Pan CC, Kou YR, Hsu YP, Ho LT: Resistin increases lipid accumulation by affecting class A scavenger receptor, CD36 and ATP-binding cassette transporter-A1 in macrophages. Life Sci 84, 97-104, 2009 doi:10.1016/j.lfs.2008.11.004

Lee WJ, Wu CS, Lin H, Lee IT, Wu CM, Tseng JJ, Chou MM, Sheu WH: Visfatin-induced expression of inflammatory mediators in human endothelial cells through the NF-kappaB pathway. Int J Obes (Lond) 33, 465-472, 2009 doi:10.1038/ijo.2009.24

Lehrke M, Reilly MP, Millington SC, Iqbal N, Rader DJ, Lazar MA: An inflammatory cascade leading to hyperresistinemia in humans. PLoS Med 1, e45, 2004 doi:10.1371/journal.pmed.0010045 Li L, Yang G, Shi S, Yang M, Liu H, Boden G: The adipose triglyceride lipase, adiponectin and visfatin are downregulated by tumor necrosis factor-alpha (TNF-alpha) in vivo. Cytokine 45, 12-19, 2009 doi:10.1016/j.cyto.2008.10.006

Li Y, Totsune K, Takeda K, Furuyama K, Shibahara S, Takahashi K: Differential expression of adrenomedullin and resistin in 3T3-L1 adipocytes treated with tumor necrosis factor-alpha. Eur J Endocrinol 149, 231-238, 2003 doi:10.1530/eje.0.1490231

Liu F, Fan HQ, Qiu J, Wang B, Zhang M, Gu N, Zhang CM, Fei L, Pan XQ, Guo M, Chen RH, Guo XR: A paradox: insulin inhibits expression and secretion of resistin which induces insulin resistance. World J Gastroenterol 14, 95-100, 2008 doi:10.3748/wjg. 14.95 
Liu X, Ji Y, Chen J, Li S, Luo F: Circulating visfatin in chronic obstructive pulmonary disease. Nutrition 25, 373-378, 2009 doi:10.1016/j.nut.2008.09.008

Lopez-Bermejo A, Chico-Julia B, Fernandez-Balsells M, Recasens M, Esteve E, Casamitjana R, Ricart W, Fernandez-Real JM: Serum visfatin increases with progressive beta-cell deterioration. Diabetes 55, 2871-2875, $2006 \underline{\text { doi:10.2337/ }}$ db06-0259

Lu SC, Shieh WY, Chen CY, Hsu SC, Chen HL: Lipopolysaccharide increases resistin gene expression in vivo and in vitro. FEBS Lett 530, 158-162, 2002 doi:10.1016/S0014-5793(02)03450-6

Maebuchi M, Machidori M, Urade R, Ogawa T, Moriyama T: Low resistin levels in adipose tissues and serum in highfat fed mice and genetically obese mice: development of an ELISA system for quantification of resistin. Arch Biochem Biophys 416, 164-170, 2003 doi:10.1016/S0003-9861(03)00279-0

Manco M, Fernandez-Real JM, Equitani F, Vendrell J, Valera Mora ME, Nanni G, Tondolo V, Calvani M, Ricart W, Castagneto M, Mingrone G: Effect of massive weight loss on inflammatory adipocytokines and the innate immune system in morbidly obese women. J Clin Endocrinol Metab 92, 483-490, 2007 doi:10.1210/jc.2006-0960

Marcinkowska M, Lewandowski KC, Lewinski A, Bienkiewicz M, Basinska-Lewandowska M, Salata I, Randeva HS: Visfatin levels do not change after the oral glucose tolerance test and after a dexamethasone-induced increase in insulin resistance in humans. Endokrynol Pol 58, 188-194, 2007

Matsui H, Tsutsumi A, Sugihara M, Suzuki T, Iwanami K, Kohno M, Goto D, Matsumoto I, Ito S, Sumida T: Visfatin (pre-B cell colony-enhancing factor) gene expression in patients with rheumatoid arthritis. Ann Rheum Dis 67, 571-572, 2008 doi:10.1136/ard.2007.077578

Mercader J, Granados N, Caimari A, Oliver P, Bonet ML, Palou A: Retinol-binding protein 4 and nicotinamide phosphoribosyltransferase/visfatin in rat obesity models. Horm Metab Res 40, 467-472, 2008 doi:10.1055/s-20081065324

Migita K, Maeda Y, Miyashita T, Kimura H, Nakamura M, Ishibashi H, Eguchi K: The serum levels of resistin in rheumatoid arthritis patients. Clin Exp Rheumatol 24, 698-701, 2006

Milan G, Granzotto M, Scarda A, Calcagno A, Pagano C, Federspil G, Vettor R: Resistin and adiponectin expression in visceral fat of obese rats: effect of weight loss. Obes Res 10, 1095-1103, 2002 doi:10.1038/oby.2002.149

Moon B, Kwan JJ, Duddy N, Sweeney G, Begum N: Resistin inhibits glucose uptake in L6 cells independently of changes in insulin signaling and GLUT4 translocation. Am J Physiol Endocrinol Metab 285, E106-E115, 2003

Morash BA, Willkinson D, Ur E, Wilkinson M: Resistin expression and regulation in mouse pituitary. FEBS Lett 526, 26-30, 2002 doi:10.1016/S0014-5793(02)03108-3

Moschen AR, Kaser A, Enrich B, Mosheimer B, Theurl M, Niederegger H, Tilg H: Visfatin, an adipocytokine with proinflammatory and immunomodulating properties. J Immunol 178, 1748-1758, 2007

Nagaev I, Smith U: Insulin resistance and type 2 diabetes are not related to resistin expression in human fat cells or skeletal muscle. Biochem Biophys Res Commun 285, 561-564, 2001 doi:10.1006/bbrc.2001.5173

Nogueiras R, Gualillo O, Caminos JE, Casanueva FF, Dieguez C: Regulation of resistin by gonadal, thyroid hormone, and nutritional status. Obes Res 11, 408-414, 2003 doi:10.1038/oby.2003.55

Nowell MA, Richards PJ, Fielding CA, Ognjanovic S, Topley N, Williams AS, Bryant-Greenwood G, Jones SA: Regulation of pre-B cell colony-enhancing factor by STAT-3-dependent interleukin-6 trans-signaling: implications in the pathogenesis of rheumatoid arthritis. Arthritis Rheum 54, 2084-2095, 2006 doi:10.1002/art.21942

Otero M, Lago R, Gomez R, Lago F, Dieguez C, Gomez-Reino JJ, Gualillo O: Changes in plasma levels of fat-derived hormones adiponectin, leptin, resistin and visfatin in patients with rheumatoid arthritis. Ann Rheum Dis 65, 1198-1201, 2006 doi:10.1136/ard.2005.046540

Pagano C, Pilon C, Olivieri M, Mason P, Fabris R, Serra R, Milan G, Rossato M, Federspil G, Vettor R: Reduced plasma visfatin/pre-B cell colony-enhancing factor in obesity is not related to insulin resistance in humans. J Clin Endocrinol Metab 91, 3165-3170, 2006 doi:10.1210/jc.2006-0361

Palanivel R, Maida A, Liu Y, Sweeney G: Regulation of insulin signalling, glucose uptake and metabolism in rat skeletal muscle cells upon prolonged exposure to resistin. Diabetologia 49, 183-190, 2006 doi:10.1007/s00125-005-0060-Z

Patel L, Buckels AC, Kinghorn IJ, Murdock PR, Holbrook JD, Plumpton C, Macphee CH, Smith SA: Resistin is expressed in human macrophages and directly regulated by PPAR gamma activators. Biochem Biophys Res Commun 300 , 472-476, 2003 doi:10.1016/S0006-291X(02)02841-3

Pravenec M, Kazdova L, Cahova M, Landa V, Zidek V, Mlejnek P, Simakova M, Wang J, Qi N, Kurtz TW: Fat-specific transgenic expression of resistin in the spontaneously hypertensive rat impairs fatty acid re-esterification. Int J Obes (Lond) 30, 1157-1159, 2006 doi:10.1038/sj.ijo.0803237

Qin S, Li L, Yang GY, Li RZ, Li K, Qi XY, Li SB, Chen WW, Liu H, Tang Y, Boden G: Effects of visfatin gene overexpression on insulin sensitivity in the insulin-resistant rats induced by high-fat diet. Zhonghua Yi Xue Za Zhi 88,365-368, 2008 
Rajala MW, Qi Y, Patel HR, Takahashi N, Banerjee R, Pajvani UB, Sinha MK, Gingerich RL, Scherer PE, Ahima RS: Regulation of resistin expression and circulating levels in obesity, diabetes, and fasting. Diabetes 53, 1671-1679, 2004 doi:10.2337/diabetes.53.7.1671

Revollo JR, Korner A, Mills KF, Satoh A, Wang T, Garten A, Dasgupta B, Sasaki Y, Wolberger C, Townsend RR, Milbrandt J, Kiess W, Imai S: Nampt/PBEF/Visfatin regulates insulin secretion in beta cells as a systemic NAD biosynthetic enzyme. Cell Metab 6, 363-375, 2007 doi:10.1016/j.cmet.2007.09.003

Rongvaux A, Shea RJ, Mulks MH, Gigot D, Urbain J, Leo O, Andris F: Pre-B-cell colony-enhancing factor, whose expression is up-regulated in activated lymphocytes, is a nicotinamide phosphoribosyltransferase, a cytosolic enzyme involved in NAD biosynthesis. Eur J Immunol 32, 3225-3234, 2002 doi:10.1002/1521-4141(200211)32:11<3225:: AID-IMMU3225>3.0.CO;2-L

Rongvaux A, Galli M, Denanglaire S, Van Gool F, Dreze PL, Szpirer C, Bureau F, Andris F, Leo O: Nicotinamide phosphoribosyl transferase/pre-B cell colony-enhancing factor/visfatin is required for lymphocyte development and cellular resistance to genotoxic stress. J Immunol 181, 4685-4695, 2008

Samal B, Sun Y, Stearns G, Xie C, Suggs S, McNiece I: Cloning and characterization of the cDNA encoding a novel human pre-B-cell colony-enhancing factor. Mol Cell Biol 14, 1431-1437, 1994 Savage DB, Sewter CP, Klenk ES, Segal DG, Vidal-Puig A, Considine RV, O'Rahilly S: Resistin / Fizz3 expression in relation to obesity and peroxisome proliferator-activated receptor-gamma action in humans. Diabetes 50, 2199-2202, 2001 doi:10.2337/ diabetes.50.10.2199

Senolt L, Housa D, Vernerová Z, Jirasek T, Svobodova R, Veigl D, Anderlova K, Muller-Ladner U, Pavelka K, Haluzik M: Resistin in rheumatoid arthritis synovial tissue, synovial fluid and serum. Ann Rheum Dis 66, 458-463, 2007 doi:10.1136/ard.2006.054734

Sheng CH, Di J, Jin Y, Zhang YC, Wu M, Sun Y, Zhang GZ: Resistin is expressed in human hepatocytes and induces insulin resistance. Endocrine 33, 135-143, 2008 doi:10.1007/s12020-008-9065-y

Sheu WH, Chang TM, Lee WJ, Ou HC, Wu CM, Tseng LN, Lang HF, Wu CS, Wan CJ, Lee IT: Effect of weight loss on proinflammatory state of mononuclear cells in obese women. Obesity (Silver Spring) 16, 1033-1038, 2008 doi:10.1038/oby.2008.37

Shojima N, Sakoda H, Ogihara T, Fujishiro M, Katagiri H, Anai M, Onishi Y, Ono H, Inukai K, Abe M, Fukushima Y, Kikuchi M, Oka Y, Asano T: Humoral regulation of resistin expression in 3T3-L1 and mouse adipose cells. Diabetes 51, 1737-1744, 2002 doi:10.2337/diabetes.51.6.1737

Silswal N, Singh AK, Aruna B, Mukhopadhyay S, Ghosh S, Ehtesham NZ: Human resistin stimulates the pro-inflammatory cytokines TNF-alpha and IL-12 in macrophages by NF-kappaB-dependent pathway. Biochem Biophys Res Commun 334, 1092-1101, 2005 doi:10.1016/j.bbrc.2005.06.202

Song HK, Lee MH, Kim BK, Park YG, Ko GJ, Kang YS, Han JY, Han SY, Han KH, Kim HK, Cha DR: Visfatin: a new player in mesangial cell physiology and diabetic nephropathy. Am J Physiol Renal Physiol 295, F1485-F1494, 2008 doi:10.1152/ajprenal.90231.2008

Steppan CM, Bailey ST, Bhat S, Brown EJ, Banerjee RR, Wright CM, Patel HR, Ahima RS, Lazar MA: The hormone resistin links obesity to diabetes. Nature 409, 307-312, 2001 doi:10.1038/35053000

Steppan CM, Wang J, Whiteman EL, Birnbaum MJ, Lazar MA: Activation of SOCS-3 by resistin. Mol Cell Biol 25, 1569-1575, 2005 doi:10.1128/MCB.25.4.1569-1575.2005 Stofkova A, Skurlova M, Kiss A, Zelezna B, Zorad S, Jurcovicova J: Activation of hypothalamic NPY, AgRP, MC4R, and IL-6 mRNA levels in young Lewis rats with early-life diet-induced obesity. Endocrine Regul 43, 99-106, 2009

Sun G, Bishop J, Khalili S, Vasdev S, Gill V, Pace D, Fitzpatrick D, Randell E, Xie YG, Zhang H: Serum visfatin concentrations are positively correlated with serum triacylglycerols and down-regulated by overfeeding in healthy young men. Am J Clin Nutr 85, 399-404, 2007

Sun Q, Li L, Li R, Yang M, Liu H, Nowicki MJ, Zong H, Xu J, Yang G: Overexpression of visfatin/PBEF/Nampt alters wholebody insulin sensitivity and lipid profile in rats. Ann Med 41, 311-312, 2009 doi:10.1080/07853890902729760

Tovar S, Nogueiras R, Tung LY, Castaneda TR, Vazquez MJ, Morris A, Williams LM, Dickson SL, Dieguez C: Central administration of resistin promotes short-term satiety in rats. Eur J Endocrinol 153, R1-R5, 2005 doi:10.1530/ eje.1.01999

Valsamakis G, McTernan PG, Chetty R, Al Daghri N, Field A, Hanif W, Barnett AH, Kumar S: Modest weight loss and reduction in waist circumference after medical treatment are associated with favorable changes in serum adipocytokines. Metabolism 53, 430-434, 2004 doi:10.1016/j.metabol.2003.11.022

Vazquez MJ, Gonzalez CR, Varela L, Lage R, Tovar S, Sangiao-Alvarellos S, Williams LM, Vidal-Puig A, Nogueiras R, Lopez M, Dieguez C: Central resistin regulates hypothalamic and peripheral lipid metabolism in a nutritionaldependent fashion. Endocrinology 149, 4534-4543, 2008 doi:10.1210/en.2007-1708 
Verma S, Li SH, Wang CH, Fedak PW, Li RK, Weisel RD, Mickle DA: Resistin promotes endothelial cell activation: further evidence of adipokine-endothelial interaction. Circulation 108, 736-740, 2003 doi:10.1161/01. CIR.0000084503.91330.49

Way JM, Gorgun CZ, Tong Q, Uysal KT, Brown KK, Harrington WW, Oliver WR Jr, Willson TM, Kliewer SA, Hotamisligil GS: Adipose tissue resistin expression is severely suppressed in obesity and stimulated by peroxisome proliferator-activated receptor gamma agonists. J Biol Chem 276, 25651-25653, 2001 doi:10.1074/jbc.C100189200

Xie H, Tang SY, Luo XH, Huang J, Cui RR, Yuan LQ, Zhou HD, Wu XP, Liao EY: Insulin-like effects of visfatin on human osteoblasts. Calcif Tissue Int 80, 201-210, 2007 doi:10.1007/s00223-006-0155-7

Ye SQ, Simon BA, Maloney JP, Zambelli-Weiner A, Gao L, Grant A, Easley RB, McVerry BJ, Tuder RM, Standiford T, Brower RG, Barnes KC, Garcia JG: Pre-B-cell colony-enhancing factor as a potential novel biomarker in acute lung injury. Am J Respir Crit Care Med 171, 361-370, 2005 doi:10.1164/rccm.200404-563OC

Zahorska-Markiewicz B, Olszanecka-Glinianowicz M, Janowska J, Kocelak P, Semik-Grabarczyk E, Holecki M, Dabrowski P, Skorupa A: Serum concentration of visfatin in obese women. Metabolism 56, 1131-1134, 2007 doi:10.1016/ j.metabol.2007.04.007 